\title{
НАЛЕЖНЕ ЗАБЕЗПЕЧЕННЯ ВИЩОЇ ОСВІТИ НАВЧАЛЬНОЮ КНИГОЮ - НЕВІД'ЄМНА СКЛАДОВА ЗАБЕЗПЕЧЕННЯ ЯКОСТІ ОСВІТНЬОЇ ДІЯЛЬНОСТІ
}

\author{
Ю. С. П’ятницький ${ }^{1}$, Н. О. Олексіна ${ }^{1}$, Р. А. Стецюк ${ }^{1}$, І. В. Мельник ${ }^{2}$, Т. І. Фаріон ${ }^{2}$ \\ ${ }^{1}$ Міністерство охорони здоров'я України,

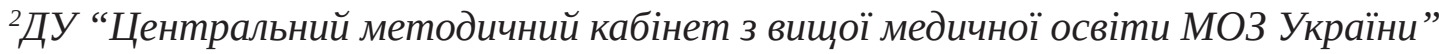

\section{APPROPRIATE PROVISION OF HIGHER EDUCATION WITH TEXT BOOK - INSEPARABLE PART OF EDUCATIONAL QUALITY}

\author{
Yu. S. Pyatnytskyi ${ }^{1}$, N. O. Oleksina ${ }^{1}$, R. A. Stetsyuk ${ }^{1}$, I. V. Melnyk ${ }^{2}$, T. I. Farion ${ }^{2}$ \\ ${ }^{1}$ Ministry of Health of Ukraine, \\ ${ }^{2} S I$ "Central methodical cabinet of higher medical education Ministry of Health of Ukraine"
}

\begin{abstract}
У статті наведено аналіз забезпеченості студентів вищих медичних та фармацевтичних навчальних закладів навчальнометодичною літературою.
\end{abstract}

The article presents analysis of students' provision of medical and pharmaceutical universities by educational and teaching literature.

Вступ. Належне забезпечення здобувачів вищої освіти сучасною навчально-методичною літературою є невід 'ємною складовою забезпечення якості організації навчального процесу у вищих навчальних закладах та забезпечує виконання статті 16 розділу V Закону України “Про вищу освіту” [1].

Відповідно до Ліцензійних умов провадження освітньої діяльності закладів освіти, затверджених Постановою Кабінету Міністрів України від 30.12.2015 р. № 1187 (далі - Ліцензійні умови), забезпеченість студентів навчальними матеріалами 3 кожної навчальної дисципліни навчального плану включена до розділу “Технологічні вимоги щодо навчально-методичного забезпечення провадження освітньої діяльності у сфері вищої освіти” (додаток 14 до Ліцензійних умов) [2]. При цьому “....забезпеченістю навчальними матеріалами вважається наявність підручників, навчальних посібників, конспектів лекцій, хрестоматій згідно з переліком рекомендованої літератури з розрахунку: один примірник на п’ять осіб фактичного контингенту студентів та заявленого додаткового ліцензованого обсягу в разі розширення провадження освітньої діяльності...”.

Основна частина. У 2015/2016 навчальному році аналіз забезпеченості студентів навчально() Ю. С. П’ятницький, Н. О. Олексіна, Р. А. Стецюк та ін. методичною літературою ще здійснювався з урахуванням Ліцензійних умов надання освітніх послуг у сфері вищої освіти, затверджених наказом Міністерства освіти і науки України від 24.12.2003 р. № 847, а саме з розрахунку: одна навчальна книга на трьох студентів, що одночасно вивчають дану дисципліну.

Дані щорічного моніторингу забезпечення студентів сучасними підручниками та посібниками, виданими державною мовою на паперових носіях протягом останніх п’яти років, який проводить Державна установа “Центральний методичний кабінет з вищої медичної освіти МОЗ України” (далі - ЦМК), свідчать, що у 2015/2016 навчальному році зберігається тенденція до збільшення показників забезпечення студентів усіх спеціальностей навчальними книгами (табл. 1).

Необхідно зазначити, що, ураховуючи пункт 3 наказу МОН України від 18.04.2014 р. № 486 “Деякі питання скасування процедури надання МОН України грифів навчальній літературі для вищих навчальних закладів”, а також той факт, що останнє засідання Комісії з медицини Науково-методичної ради з питань освіти Міністерства освіти і науки України (наказ МОН України від 25.11.2011 р. № 1364), на якому б розглядались рукописи з метою подання їх 
Таблиця 1. Показники забезпечення підручниками і посібниками студентів ВНЗ МОЗ України за спеціальностями (2014 - 2015 рр.)

\begin{tabular}{|c|c|c|c|c|c|c|c|c|}
\hline & \multicolumn{2}{|c|}{$\begin{array}{c}\text { “Лiкувальна справа”, } \\
\text { “Педіатрія” та “Медико- } \\
\text { профілактична справа” }\end{array}$} & \multicolumn{2}{|c|}{ “Стоматологія” } & \multicolumn{2}{|c|}{ “Медична психологія” } & \multicolumn{3}{|c|}{ “Фармація” } \\
\cline { 2 - 10 } & підручники & посібники & підручники & посібники & підручники & посібники & підручники & посібники \\
\hline 2014 & 34 & 18 & 30 & 16 & 34 & 22 & 16 & 16 \\
\hline 2015 & 35 & 17 & 33 & 13 & 37 & 22 & 21 & 15 \\
\hline
\end{tabular}

до МОН України для отримання відповідного грифа, відбулось у січні 2015 р., під час аналізу забезпечення дисциплін навчальною літературою у 2015/2016 навчальному році (станом на 01.09.2015 р.) враховані навчально-методичні книги, які видані за дозволами вчених рад ВНЗ МОЗ України та надійшли до фондів бібліотек з вересня 2014 р.

Окрім того, коли ЦМК здійснювало рецензування підручників та відповідних матеріалів на здобуття Державної премії України в галузі науки і техніки 2016 р., відповідно до критеріїв, зазначених у Порядку висунення Міністерством освіти і науки України підручників на здобуття Державної премії в галузі науки і техніки, схваленому рішен- ням колегії Міністерства освіти і науки України від 26.06.2014 р. № 4/6-19 [7], розглядались лише ті роботи, які видані до 2014 р. і мали відповідні грифи МОН України.

Станом на 01.09.2015 р. забезпечення дисциплін навчальних планів додипломної підготовки лікарів зі спеціальностей “Лікувальна справа”, “Педіатрія” та “Медико-профілактична справа” залишається на рівні 2014 р. і становить 35 \% підручниками та 17 \% посібниками (табл. 2), при цьому найкращі показники забезпеченості підручниками залишаються, як і у 2014 р., у Національного медичного університету імені О. О. Богомольця та Запорізького державного медичного університету (табл. 3).

Таблиця 2. Динаміка забезпечення підручниками і посібниками студентів медичних факультетів ВНЗ МОЗ України зі спеціальностей “Лікувальна справа”, “Педіатрія” та “Медико-профілактична справа”

протягом 2011 - 2015 рр. (державна мова, термін використання - 5 років)

\begin{tabular}{|c|c|c|}
\hline Рік проведення обрахунків & Забезпечення підручниками (\%) & Забезпечення посібниками (\%) \\
\hline 2011 & 28 & 27 \\
\hline 2012 & 37 & 39 \\
\hline 2013 & 35 & 18 \\
\hline 2014 & 34 & 17 \\
\hline 215 & 35 & \\
\hline
\end{tabular}

Таблиця 3. Забезпечення підручниками і посібниками студентів спеціальностей “Лікувальна справа”, “Педіатрія”, “Медико-профілактична справа” по ВНЗ МОЗ України (державна мова, термін використання - 5 років)

\begin{tabular}{|c|c|c|c|c|c|c|c|c|c|c|c|c|}
\hline \multirow{2}{*}{ ВНЗ } & \multicolumn{2}{|c|}{$\begin{array}{c}\text { БДМУ } \\
\text { (*лікув. справа) }\end{array}$} & \multicolumn{2}{|c|}{ ВНМУ } & \multicolumn{2}{|c|}{ ДМА } & \multicolumn{2}{|c|}{ ЗДМУ } & \multicolumn{3}{|c|}{ ІФНМУ } & \multicolumn{2}{|c|}{ ЛНМУ } \\
\hline роки & 2014 & 2015 & 2014 & 2015 & 2014 & 2015 & 2014 & 2015 & 2014 & 2015 & 2014 & 2015 \\
\hline Підр. & 30 & 51 & 26 & 29 & 41 & 43 & 55 & 54 & 31 & 23 & 30 & 42 \\
\hline Пос. & 20 & 40 & 9 & 2 & 11 & 8 & 45 & 36 & 16 & 7 & 16 & 15 \\
\hline
\end{tabular}

\begin{tabular}{|l|c|c|c|c|c|c|c|c|c|c|}
\hline ВНЗ & \multicolumn{2}{|c|}{ НМУ } & \multicolumn{2}{c|}{ ОНМУ } & \multicolumn{2}{c|}{ ТДМУ } & \multicolumn{2}{c|}{ УМСА } & \multicolumn{2}{c|}{ ХНМУ } \\
\hline роки & 2014 & 2015 & 2014 & 2015 & 2014 & 2015 & 2014 & 2015 & 2014 & 2015 \\
\hline Підр. & 58 & 55 & 8 & 9 & 29 & 39 & 22 & 28 & 40 & 36 \\
\hline Пос. & 26 & 27 & 5 & 7 & 31 & 35 & 8 & 7 & 14 & 8 \\
\hline
\end{tabular}

\begin{tabular}{|l|c|c|c|c|}
\hline \multicolumn{1}{|c|}{ ВНЗ } & \multicolumn{2}{c|}{ ДНМУ (без грифів) } & \multicolumn{2}{c|}{ Сер.\% } \\
\hline \multicolumn{1}{|c|}{ роки } & 2014 & 2015 & 2014 & 2015 \\
\hline Підр. & & 6 & 34 & 35 \\
\hline Пос. & & 6 & 18 & 17 \\
\hline
\end{tabular}




\section{Матеріали ХІІІ Всеукраїнської науково-практичної конференції з міжнародною участю “АКТУАЛЬНІ ПИТАННЯ ЯКОСТІ МЕДИЧНОЇ ОСВІТИ”}

Як свідчать показники, зазначені у таблиці 4, зріс відсоток забезпечення підручниками гуманітар-

природничо-наукової підготовки, суттєво не зміниних та соціально-економічних дисциплін та блоку лись показники забезпечення підручниками і посібниками професійно-орієнтованих дисциплін.

Таблиця 4. Забезпечення підручниками та посібниками по блоках дисциплін (спеціальності “Лікувальна справа”, “Педіатрія”, “Медико-профілактична справа”)

\begin{tabular}{|l|c|c|c|c|c|c|}
\hline & 2011 & 2012 & 2013 & 2014 & 2015 \\
\hline \multicolumn{7}{|c|}{ Гуманітарні та соціально-економічні дисципліни } \\
\hline Підручники, \% & 17 & 32 & 20 & 19 & 27 \\
\hline Посібники, \% & 23 & 44 & 30 & 23 & 14 \\
\hline \multicolumn{7}{|c|}{ Природничо-наукові дисципліни } \\
\hline Підручники, \% & 33 & 42 & 29 & 30 & 35 \\
\hline Посібники, \% & 26 & 42 & 24 & 16 & 15 \\
\hline \multicolumn{7}{|c|}{ Професійно-орієнтовані дисципліни } \\
\hline Підручники, \% & 34 & 40 & 39 & 36 & 36 \\
\hline Посібники, \% & 31 & 34 & 31 & 18 & 17 \\
\hline
\end{tabular}

Найменш забезпеченими залишаються дисципліни “Історія медицини”, “Медична біологія”, “Сестринська практика”, “Біостатистика”, “Клі- нічна фармакологія”, “Медична генетика” та інші (табл. 5).

Таблиця 5. Забезпечення підручниками і посібниками дисциплін спеціальностей “Лікувальна справа”, “Педіатрія” та “Медико-профілактична справа” (державна мова, термін використання - 5 років)

\begin{tabular}{|c|c|c|c|c|}
\hline \multirow{3}{*}{ Назва дисципліни } & \multicolumn{4}{|c|}{ Забезпечення (\%) } \\
\hline & \multicolumn{2}{|c|}{ підручники } & \multicolumn{2}{|c|}{ посібники } \\
\hline & 2014 & 2015 & 2014 & 2015 \\
\hline Історія медицини & 9 & 18 & - & - \\
\hline Медична біологія & - & - & 20 & 17 \\
\hline Патоморфологія & 8 & 4 & 9 & 17 \\
\hline Сестринська практика & 14 & 4 & - & 1 \\
\hline Біостатистика & - & - & 9 & 8 \\
\hline Фтизіатрія & 9 & 49 & 37 & 33 \\
\hline Медична інформатика & - & 8 & 18 & 19 \\
\hline Основи біоетики та біобезпеки & 29 & 28 & 14 & 13 \\
\hline Оториноларингологія & 66 & 30 & 1 & - \\
\hline Дерматологія, венерологія & 14 & 24 & 9 & 9 \\
\hline Медичне правознавство & 40 & 29 & 4 & 19 \\
\hline Клінічна фармакологія & 18 & - & 10 & 11 \\
\hline Медична психологія & - & 3 & 9 & 8 \\
\hline Фізична реабілітація, спортивна медицина & 1 & 16 & 21 & 27 \\
\hline Медична генетика & 7 & - & - & - \\
\hline Анестезіологія та інтенсивна терапія & 51 & - & 23 & 17 \\
\hline Клінічна імунологія та алергологія & 1 & 10 & 9 & 8 \\
\hline Основи стоматології & 17 & 25 & 36 & 33 \\
\hline
\end{tabular}

У 2015 р. зберігається тенденція до зростання забезпечення підручниками студентів стоматологічних факультетів. При цьому найкращі показ- ники забезпечення підручниками зберігаються у: Запорізькому державному медичному університеті (2013 р. - 56 \%; 2014 р. - 53 \%; 2015 р. - 51 \%), 
Національному медичному університеті імені О. О. Богомольця (2013 р. - 51 \%; 2014 р. - 54 \%; 2015 р. - 51 \%), ДВНЗ “Івано-Франківський національний медичний університет” (2013 р. - 23 \%; 2014 р. - 40 \%; 2015 р. - 43 \%) (табл. 6). До 47 \% у 2015 р. зріс відсоток забезпечення підручниками у ВДНЗ “Буковинський державний медичний університет” (2013 р. - 34 \%, 2014 р. - 36 \%).
Найменш забезпеченими сучасною навчальною книгою залишаються такі професійно-орієнтовані дисципліни, як: “Пропедевтика терапевтичної стоматології” (підручниками - 1 \%, посібниками - 12 \%), “Ортодонтія” (підручниками - 16 \%, посібниками - 0 \%), “Профілактика стоматологічних захворювань” (підручниками - 8 \%, посібниками $-15 \%$ (табл. 7).

Таблиця 6. Забезпечення підручниками і посібниками студентів спеціальності “Стоматологія” по ВНЗ МОЗ України (державна мова, термін використання - 5 років)

\begin{tabular}{|l|c|c|c|c|c|c|c|c|c|c|c|c|c|c|c|}
\hline ВНЗ & \multicolumn{3}{|c|}{ БДМУ } & \multicolumn{3}{c|}{ ВНМУ } & \multicolumn{3}{c|}{ ДМА } & \multicolumn{3}{c|}{ ЗДМУ } \\
\hline роки & 2013 & 2014 & 2015 & 2013 & 2014 & 2015 & 2013 & 2014 & 2015 & 2013 & 2014 & 2015 & 2013 & 2014 & 2015 \\
\hline Підр. & 34 & 36 & 47 & 19 & 18 & 25 & 24 & 23 & 31 & 56 & 53 & 51 & 23 & 40 & 43 \\
\hline Пос. & 33 & 36 & 35 & 8 & 5 & 1 & 5 & 6 & 2 & 43 & 42 & 32 & 10 & 11 & 11 \\
\hline
\end{tabular}

\begin{tabular}{|l|c|c|c|c|c|c|c|c|c|c|c|c|c|c|c|}
\hline ВНЗ & \multicolumn{3}{|c|}{ ЛНМУ } & \multicolumn{3}{c|}{ НМУ } & \multicolumn{3}{c|}{ ОНМУ } & \multicolumn{3}{c|}{ ТДМУ } & \multicolumn{3}{c|}{ УМСА } \\
\hline роки & 2013 & 2014 & 2015 & 2013 & 2014 & 2015 & 2013 & 2014 & 2015 & 2013 & 2014 & 2015 & 2013 & 2014 & 2015 \\
\hline Підр. & 26 & 21 & 33 & 51 & 54 & 51 & 4 & 8 & 9 & 11 & 20 & 29 & 21 & 30 & 35 \\
\hline Пос. & 16 & 11 & 13 & 25 & 24 & 24 & 18 & 3 & 5 & 10 & 16 & 15 & 9 & 7 & 7 \\
\hline
\end{tabular}

\begin{tabular}{|l|c|c|c|c|c|c|c|c|c|}
\hline ВНЗ & \multicolumn{3}{|c|}{ ХНМУ } & \multicolumn{3}{c|}{ ДНМУ (без грифів) } & \multicolumn{3}{c|}{ Сер.\% } \\
\hline роки & 2013 & 2014 & 2015 & 2013 & 2014 & 2015 & 2013 & 2014 & 2015 \\
\hline Підр. & 15 & 30 & 32 & & & 7 & 28 & 30 & 33 \\
\hline Пос. & 8 & 9 & 7 & & & 9 & 22 & 16 & 13 \\
\hline
\end{tabular}

Таблиця 7. Забезпечення підручниками та посібниками дисциплін спеціальності “Стоматологія” (державна мова, термін використання - 5 років)

\begin{tabular}{|l|c|c|c|c|}
\hline \multirow{2}{*}{ Назва дисципліни } & \multicolumn{3}{|c|}{ Забезпечення (\%) } \\
\cline { 2 - 5 } & \multicolumn{2}{|c|}{ підручники } & \multicolumn{2}{|c|}{ посібники } \\
\cline { 2 - 5 } & 2014 & 2015 & 2014 & 2015 \\
\hline Історія медицини & 2 & 18 & - & - \\
\hline Медична біологія & - & - & 15 & 6 \\
\hline Пропедевтика терапевтичної стоматології & 10 & 1 & 9 & 12 \\
\hline Патоморфологія & 8 & 3 & 9 & 17 \\
\hline Фізична реабілітація, спортивна медицина & 1 & 13 & 18 & 17 \\
\hline Профілактика стоматологічних захворювань & 9 & 8 & 27 & 15 \\
\hline Ортодонтія & 9 & 16 & - & - \\
\hline Дитяча терапевтична стоматологія & 27 & 33 & - & 8 \\
\hline Дитяча хірургічна стоматологія & 14 & 26 & - & - \\
\hline Дерматологія, венерологія & 16 & 17 & - & 1 \\
\hline Медична психологія & - & 3 & 8 & 8 \\
\hline Клінічна фармакологія & 9 & - & 10 & 18 \\
\hline Клінічна імунологія & 1 & 10 & 10 & 8 \\
\hline
\end{tabular}

Забезпечення навчальною книгою студентів медико-психологічного факультету суттєво не змінилось у ВДНЗ “Буковинський державний медичний університет” (табл. 8). Зменшилось забезпечення посібниками у Вінницькому національному медичному університеті імені М. І. Пирогова (5 \% - у 2015 р. порівняно з $12 \%$ - у 2014 р.) та підручниками у Національному медичному університеті імені О. О. Богомольця (37 \% - у 2015 р. порівняно з $42 \%$ - y 2014 p.). 
Матеріали ХІІІ Всеукраїнської науково-практичної конференції з міжнародною участю “АКТУАЛЬНІ ПИТАННЯ ЯКОСТІ МЕДИЧНОЇ ОСВІТИ”

Таблиця 8. Забезпечення підручниками і посібниками студентів спеціальності “Медична психологія" по ВНЗ МОЗ України (державна мова, термін використання - 5 років)

\begin{tabular}{|l|c|c|c|c|c|c|c|c|c|c|c|c|}
\hline \multirow{2}{*}{ ВНЗ } & \multicolumn{3}{|c|}{ БДМУ } & \multicolumn{3}{c|}{ ВНМУ } & \multicolumn{3}{c|}{ НМУ } & \multicolumn{3}{c|}{ Сер.\% } \\
\hline роки & 2013 & 2014 & 2015 & 2013 & 2014 & 2015 & 2013 & 2014 & 2015 & 2013 & 2014 & 2015 \\
\hline Підр. & 38 & 35 & 34 & 21 & 26 & 30 & 42 & 42 & 37 & 34 & 34 & 37 \\
\hline Пос. & 37 & 32 & 31 & 12 & 12 & 5 & 22 & 22 & 22 & 22 & 22 & 22 \\
\hline
\end{tabular}

У 2015/2016 навчальному році спостерігається літературою студентів фармацевтичних факультепокращення забезпечення навчально-методичною тів (табл. 9-12).

Таблиця 9. Забезпечення підручниками і посібниками студентів спеціальності “Фармація” по ВНЗ МОЗ України (державна мова, термін використання - 5 років)

\begin{tabular}{|l|c|c|c|c|c|c|c|c|c|c|c|c|}
\hline \multirow{2}{*}{ ВНЗ } & \multicolumn{2}{|c|}{ ВНМУ } & \multicolumn{2}{c|}{ НФаУ } & \multicolumn{2}{c|}{ ДМА } & \multicolumn{2}{c|}{ ЗДМУ } & \multicolumn{2}{c|}{ ІФНМУ } & \multicolumn{2}{c|}{ ЛНМУ } \\
\cline { 2 - 15 } & 2014 & 2015 & 2014 & 2015 & 2014 & 2015 & 2014 & 2015 & 2014 & 2015 & 2014 & 2015 \\
\hline Підр. & 10 & 16 & 6 & 14 & 14 & 21 & 35 & 26 & 22 & 34 & 24 & 27 \\
\hline Пос. & 3 & 3 & 9 & 17 & 9 & 5 & 56 & 46 & 16 & 15 & 13 & 9 \\
\hline
\end{tabular}

\begin{tabular}{|c|c|c|c|c|c|c|c|c|c|c|c|c|}
\hline \multirow{2}{*}{ BH3 } & \multicolumn{2}{|c|}{ НМУ } & \multicolumn{2}{|c|}{ ОНМУ } & \multicolumn{2}{|c|}{ ТДМУ } & \multicolumn{2}{|c|}{ БДМУ } & \multicolumn{2}{|c|}{$\begin{array}{c}\text { ДНМУ } \\
\text { (без грифів) }\end{array}$} & \multicolumn{2}{|c|}{ Сер.\% } \\
\hline & 2014 & 2015 & 2014 & 2015 & 2014 & 2015 & 2014 & 2015 & 2014 & 2015 & 2014 & 2015 \\
\hline Підр. & 8 & 32 & 6 & 5 & 9 & 19 & 23 & 34 & & 4 & 16 & 21 \\
\hline Пос. & 11 & 21 & 2 & 4 & 20 & 15 & 23 & 22 & & 3 & 16 & 15 \\
\hline
\end{tabular}

Таблиця 10. Забезпечення підручниками і посібниками студентів спеціальності “Клінічна фармація” по ВНЗ МОЗ України (державна мова, термін використання - 5 років)

\begin{tabular}{|c|c|c|c|c|c|c|c|c|c|c|c|c|c|c|}
\hline \multirow{2}{*}{ ВН3 } & \multicolumn{2}{|c|}{ ВНМУ } & \multicolumn{2}{|c|}{ НФаУ } & \multicolumn{2}{|c|}{ ДМА } & \multicolumn{2}{|c|}{ ЛНМУ } & \multicolumn{2}{|c|}{ ТДМУ } & \multicolumn{2}{|c|}{ БДМУ } & \multicolumn{2}{|c|}{ Сер.\% } \\
\hline & 2014 & 2015 & 2014 & 2015 & 2014 & 2015 & 2014 & 2015 & 2014 & 2015 & 2014 & 2015 & 2014 & 2015 \\
\hline Підр. & 12 & 17 & 6 & 12 & 11 & 19 & 18 & 22 & 9 & 19 & 10 & 32 & 11 & 20 \\
\hline Пос. & 8 & 5 & 9 & 14 & 9 & 7 & 8 & 8 & 15 & 11 & 16 & 30 & 11 & 13 \\
\hline
\end{tabular}

Таблиця 11. Забезпечення підручниками і посібниками студентів

спеціальності “Технологія парфумерно-косметичних засобів”

по ВНЗ МОЗ України (державна мова, термін використання - 5 років)

\begin{tabular}{|c|c|c|c|c|c|c|c|c|c|c|}
\hline \multirow{2}{*}{ BH3 } & \multicolumn{2}{|c|}{ НФаУ } & \multicolumn{2}{|c|}{ ЗДМУ } & \multicolumn{2}{|c|}{ НМУ } & \multicolumn{2}{|c|}{ ТДМУ } & \multicolumn{2}{|c|}{ Сер.\% } \\
\hline & 2014 & 2015 & 2014 & 2015 & 2014 & 2015 & 2014 & 2015 & 2014 & 2015 \\
\hline Підр. & 6 & 16 & 28 & 21 & 13 & 27 & 9 & 16 & 14 & 20 \\
\hline Пос. & 4 & 13 & 45 & 41 & 17 & 19 & 16 & 13 & 21 & 22 \\
\hline
\end{tabular}

Таблиця 12. Забезпечення підручниками і посібниками студентів спеціальності “Технологія фармацевтичних препаратів” по ВНЗ МОЗ України (державна мова, термін використання - 5 років)

\begin{tabular}{|l|c|c|c|c|}
\hline \multirow{2}{*}{ ВНЗ } & \multicolumn{2}{|c|}{ НФаУ } & \multicolumn{2}{c|}{ Сер.\% } \\
\cline { 2 - 5 } & 2014 & 2015 & 2014 & 2015 \\
\hline Підр. & 2 & 9 & 2 & 9 \\
\hline Пос. & 3 & 14 & 3 & 14 \\
\hline
\end{tabular}


3 метою покращення забезпечення студентів сучасною навчальною книгою вищі навчальні заклади МОЗ України (далі - ВНЗ МОЗ України) вживали заходів для залучення коштів на видання та закупівлю навчально-методичної літератури. Як свідчать показники, зазначені у таблицях 13, 14 та 15, найбільше коштів на закупівлю навчальної літератури спрямовано у: Запорізькому державному медичному університеті (2 692 704,00 грн); Д3 “Дніпропетровська медична академія МОЗ України” (1 215 540,00 грн); Вінницькому національному медичному університеті імені М. І. Пирогова (956 828,00 грн). При цьому із розрахунку на одного студента найбільші показники щодо коштів, виділених на закупівлю навчальних книг, виданих українською мовою, у: ДЗ “Дніпропетровська медична академія МОЗ України” (162,56 грн); ДВНЗ “Тернопільський державний медичний університет імені I. Я. Горбачевського МО3 України” (147,45 грн); ВДНЗ “Буковинський державний медичний університет” (136,00 грн); російською - у Д3 “Дніпропетровська медична академія МОЗ України” (524,59 грн); Запорізькому державному медичному університеті (280,64 грн); Харківському національному медичному університеті (153,91 грн); іноземною - у Запорізькому державному медичному університеті (1 951,94 грн); Д3 “Дніпропетровська медична академія МОЗ України” (298,50 грн); ВДНЗ України “Українська медична стоматологічна академія” (119,39 грн).
Найбільше коштів на видання навчальної літератури у 2015 р. спрямовано у: ДВНЗ “Тернопільський державний медичний університет імені I. Я. Горбачевського МОЗ України” (1 214 063,10 грн., 3 них 88,6 \% - українською мовою); Національному фармацевтичному університеті (772 213,00 грн 3 них 67,3 \% - українською мовою); Запорізькому державному медичному університеті (436 000,00 грн, 3 них 87,0 \% - українською мовою).

При цьому у всіх ВНЗ МОЗ України переважна кількість навчально-методичної літератури була видана українською мовою.

Підсумки моніторингу навчально-методичної діяльності вищих медичних та фармацевтичних навчальних закладів і закладів післядипломної освіти, підпорядкованих МОЗ України, проведеного на виконання наказу МОЗ України від 24.10.2012 р. № 834 “Про навчально-методичну діяльність вищих медичних та фармацевтичних навчальних закладів I-IV рівнів акредитації” та відповідно до Графіка моніторингу навчальнометодичної діяльності вищих медичних та фармацевтичних навчальних закладів та закладів післядипломної освіти, підпорядкованих МОЗ України, на 2016 р., затвердженого міністром охорони здоров'я О. Квіташвілі 14.01.2016 р., свідчать про те, що у ВНЗ МОЗ України здійснювалась закупівля навчально-методичної літератури з питань військово-медичної тематики (лист ЦМК від 09.06.2015 р. № 23-01-9/246) [1].

Таблиця 13. Дані про кошти, спрямовані ВНЗ МОЗ України на закупівлю навчальної літератури протягом 2011-2015 рр. (грн)

\begin{tabular}{|c|c|c|c|c|c|}
\hline Назва ВНЗ & 2011 р. & 2012 р. & 2013 p. & 2014 p. & 2015 p. \\
\hline БДМУ & 177428,00 & 232405,00 & 215127,40 & 439438,50 & 640930,00 \\
\hline ВНМУ & 489553,80 & 750741,80 & 653140,00 & 682064,00 & 956828,00 \\
\hline ДМА & 286058,00 & 241750,00 & 755970,00 & 824200,00 & 1215540,00 \\
\hline ЗДМУ & 287283,00 & 268480,00 & 426890,00 & 293600,00 & 2692704,00 \\
\hline ІФНМУ & 111162,50 & 223787,01 & 361029,73 & 297417,17 & 685386,13 \\
\hline ЛНМУ & 295145,00 & 602818,00 & 351555,00 & 458550,00 & 539476,27 \\
\hline НМУ & 1988931,0 & 2804047,00 & не надано & 331260,00 & 738375,00 \\
\hline НФУ & 924504,00 & 33618,00 & 686851,00 & 300611,00 & 566688,85 \\
\hline ОНМУ & 327044,25 & 252267,00 & 198500,00 & 392327,00 & 140077,00 \\
\hline ТДМУ & 196860,00 & 203329,00 & 57742,00 & 193510,00 & 503178,90 \\
\hline УМСА & 250565,00 & 349444,00 & 343189,00 & 479520,00 & 278170,00 \\
\hline ХНМУ & 399270,00 & 615165,00 & 768166,00 & 277580,00 & 794653,50 \\
\hline
\end{tabular}


Таблиця 14. Кошти на закупівлю навчальної літератури (на одного студента) у $2012-2015$ рр. (грн)

\begin{tabular}{|l|c|c|c|c|c|c|c|c|c|c|c|c|}
\hline \multirow{2}{*}{ ВНЗ } & \multicolumn{4}{|c|}{ Українською } & \multicolumn{4}{c|}{ Російською } & \multicolumn{4}{c|}{ Іноземною } \\
\cline { 2 - 14 } & 2012 & 2013 & 2014 & 2015 & 2012 & 2013 & 2014 & 2015 & 2012 & 2013 & 2014 & 2015 \\
\hline БДМУ & 41,86 & 46,00 & 89,80 & 136,00 & - & - & - & - & 108,55 & 55,00 & 83,60 & 52,00 \\
\hline ВНМУ & 80,80 & 100,95 & 75,80 & 107,30 & 22,60 & 45,45 & 75,41 & 105,80 & 11,00 & 54,01 & 98,65 & 70,00 \\
\hline ДМА & 35,39 & 159,00 & 168,28 & 162,56 & 63,76 & 169,16 & 149,38 & 524,59 & 260,28 & 70,98 & 86,31 & 298,50 \\
\hline ЗДМУ & 41,60 & 71,50 & 39,40 & 90,52 & 28,20 & 171,4 & 86,90 & 280,64 & 37,90 & 54,66 & 58,60 & 1951,94 \\
\hline ІФНМУ & 39,01 & 64,26 & 51,35 & 52,10 & 14,98 & 155,51 & 53,11 & 69,53 & 63,27 & 56,87 & 49,71 & 25,83 \\
\hline ЛНМУ & 122,50 & 68,50 & 88,00 & 112,49 & 660,00 & 87,00 & 18,00 & - & 130,60 & 100,87 & 82,00 & 36,53 \\
\hline НМУ & 208,09 & $\begin{array}{c}\text { не нада- } \\
\text { но }\end{array}$ & 12,66 & 31,97 & 473,82 & не нада- & 137,49 & 17,11 & 802,63 & не нада- & 120,48 & 18,09 \\
\hline НФУ & 4,38 & 61,85 & 34,46 & 53,35 & 0,58 & 27,02 & 23,41 & 89,80 & - & 309,85 & 10,81 & 69,91 \\
\hline ОНМУ & 50,30 & 45,10 & 58,00 & 4,40 & 31,90 & - & 110,00 & 147,00 & 67,20 & - & 20,00 & - \\
\hline ТДМУ & 50,24 & 13,16 & 53,44 & 147,45 & 185,90 & 32,82 & 105,00 & 12,62 & 57,40 & 18,70 & 19,48 & 16,09 \\
\hline УМСА & 81,70 & 79,70 & 84,07 & 57,13 & 97,76 & 61,03 & 266,65 & 48,53 & 290,41 & 190,38 & 74,53 & 119,39 \\
\hline ХНМУ & 51,25 & 143,64 & 29,39 & 121,53 & 222,70 & 70,05 & 72,78 & 153,91 & 157,43 & 98,47 & 38,59 & 54,67 \\
\hline
\end{tabular}

Таблиця 15. Дані про кошти, спрямовані ВНЗ МОЗ України на видання навчальної літератури у 2013 - 2015 pp.

\begin{tabular}{|c|c|c|c|c|c|c|c|c|c|}
\hline \multirow[b]{2}{*}{$\begin{array}{c}\text { Назва } \\
\text { ВНЗ }\end{array}$} & \multirow{2}{*}{$\begin{array}{c}2013 \text { р. } \\
\text { Загальна } \\
\text { сума } \\
\text { (грн) }\end{array}$} & \multicolumn{4}{|c|}{2014 p. } & \multicolumn{4}{|c|}{2015 p. } \\
\hline & & $\begin{array}{c}\text { Загальна } \\
\text { сума } \\
\text { (грн) }\end{array}$ & $\begin{array}{c}\text { Укр. мо- } \\
\text { вою } \\
\text { (\%) }\end{array}$ & $\begin{array}{c}\text { Рос. мо- } \\
\text { вою } \\
(\%)\end{array}$ & $\begin{array}{c}\text { Іноз. } \\
\text { мовою } \\
(\%)\end{array}$ & $\begin{array}{c}\text { Загальна } \\
\text { сума } \\
\text { (грн) }\end{array}$ & $\begin{array}{l}\text { Укр. } \\
\text { мовою } \\
\text { (\%) }\end{array}$ & $\begin{array}{c}\text { Рос. мо- } \\
\text { вою } \\
(\%)\end{array}$ & $\begin{array}{c}\text { Іноз. } \\
\text { мовою } \\
\text { (\%) }\end{array}$ \\
\hline БДМУ & 25000,00 & 22775,00 & 17,6 & - & 82,4 & 12790,00 & 90,0 & - & 10,0 \\
\hline BHMУ & 96535,14 & 85 142,00 & 77,0 & 7,7 & 15,3 & 74508,00 & 68,2 & 18,2 & 13,6 \\
\hline ДМА & - & - & - & - & - & - & - & - & - \\
\hline ЗДМУ & 296902,00 & 392 150,00 & 70,0 & 27,0 & 3,0 & 436000,00 & 87,0 & 10,0 & 3,0 \\
\hline IФНМУ & 70534,80 & 387726,13 & 72,0 & 4,0 & 24,0 & 257597,00 & 90,0 & 1,0 & 9,0 \\
\hline ЛНМУ & 151166,00 & 174680,00 & 58,7 & - & 41,3 & 115227,28 & 72,9 & - & 27,2 \\
\hline HMY & не надано & 331260,00 & 25,0 & 27,0 & 47,0 & - & - & - & - \\
\hline НФУ & 579021,00 & 202222,00 & 87,2 & 10,0 & 2,8 & 772 213,00 & 67,3 & 28,1 & 4,6 \\
\hline OHMY & 263940,17 & 272848,17 & 72,4 & 27,6 & - & 234549,70 & 73,1 & 26,9 & - \\
\hline ТДМУ & 434003,00 & 519697,29 & 94,8 & - & 5,3 & 1214063,1 & 88,6 & 4,4 & 7,0 \\
\hline УMCA & 100300,00 & 145700,00 & 85,0 & 10,0 & 5,0 & 170300,00 & 86,0 & 8,9 & 5,1 \\
\hline XНMУ & 91 197,00 & 56 458,30 & 37,5 & 50,5 & 12,0 & 45866,40 & 54,3 & 34,1 & 11,6 \\
\hline ДНМУ & 249346,00 & & & & & 58314,00 & - & 100,0 & - \\
\hline
\end{tabular}

Відповідно до підготовленого з урахуванням пропозицій ВНЗ МОЗ України та затвердженого ЦМК 29.01.2016 р. Оперативного плану видання навчальної та навчально-методичної літератури для студентів вищих навчальних закладів та закладів післядипломної освіти, підпорядкованих МОЗ України, на 2016 р., найбільша кількість під- ручників запланована до видання у Національному медичному університеті імені О. О. Богомольця (27), Національному фармацевтичному університеті та ДВНЗ “Тернопільський державний медичний університет імені І. Я. Горбачевського МОЗ України” (13 та 12) (табл. 16). 
Таблиця 16. Оперативний план видання навчальної та навчально-методичної літератури для студентів вищих навчальних закладів та закладів післядипломної освіти, підпорядкованих МОЗ України, на 2016 р.

\begin{tabular}{|c|c|c|c|c|}
\hline \multirow{3}{*}{ Назва ВНЗ } & \multicolumn{4}{|c|}{ Кількість запланованих до видання підручників } \\
\hline & \multicolumn{2}{|c|}{ загальна } & \multicolumn{2}{|c|}{ з них за бюджетні кошти } \\
\hline & 2015 & 2016 & 2015 & 2016 \\
\hline БДМУ & & 3 & & \\
\hline BHMY & 1 & 3 & & 1 \\
\hline ДМА & & 5 & & \\
\hline ЗДМУ & 4 & 5 & 1 & \\
\hline IФНМУ & 1 & 2 & 1 & \\
\hline ЛНМУ & 9 & 7 & & 3 \\
\hline HMY & 50 & 27 & 50 & \\
\hline НФУ & 9 & 13 & & \\
\hline OHMY & & 2 & & \\
\hline ТДМУ & 2 & 12 & & \\
\hline УMCA & & 5 & & \\
\hline XHMY & 5 & 3 & 5 & 2 \\
\hline НМАПО & 6 & 5 & & 1 \\
\hline ХМАПО & 2 & 6 & 1 & \\
\hline ЗМАПО & 3 & 1 & & \\
\hline ДНМУ & & 1 & & 1 \\
\hline ЛДМУ & & 1 & & 1 \\
\hline Всього: & 92 & 101 & 58 & 9 \\
\hline
\end{tabular}

Електронна інформатизація в медичній освіті вимагає широкого застосування у навчальному процесі електронних освітніх ресурсів. Як свідчить інформація, надана ВНЗ МОЗ України на запит ЦМК (табл. 17), станом на 01.09.2015 р., найбільша кількість електронних видань використовується у навчальному процесі: Одеського національного медичного університету (1790), Запорізького державного медичного університету (1732) та ВДНЗ України "Українська медична стоматологічна академія” (828); при цьому найбільша кількість видань, авторами яких є фахівці навчальних закладів, y: Запорізькому державному медичному університеті (1662); ВДНЗ України “Українська медична стоматологічна академія” (718); Харківському національному медичному університеті (633).

3 метою забезпечення організації підготовки електронних видань фахівцями ВНЗ МОЗ України, авторським колективом за участі фахівців МО3 України, ЦМК, Донецького національного медичного університету імені М. Горького, Національної медичної академії післядипломної освіти імені П. Л. Шупика, Запорізького державного медич- ного університету, ДВНЗ “Тернопільський державний медичний університет імені I. Я. Горбачевського МО3 України” підготовлені методичні рекомендації “Підготовка електронних видань, дидактичних демонстраційних матеріалів, електронних навчальних посібників та підручників у вищих медичних навчальних закладах”, які затверджені МОЗ України 17.09.2015 р. та надіслані до ВНЗ МОЗ України для впровадження з листом від 18.09.2015 р. № 23-01-9/443[5], а також методичні рекомендації “Підготовка електронних навчальних матеріалів (електронних підручників та навчальних посібників) до видання”, розроблені фахівцями Національної медичної академії післядипломної освіти імені П. Л. Шупика спільно з МОЗ України та ЦМК (лист МОЗ України від 27.10.2015 р. № 08.01-47/34048) [6].

Однак на теперішній час активність авторських колективів ВНЗ МОЗ України щодо створення електронних засобів методичного забезпечення процесу навчання $є$ мінімальною. Сподіваємось на те, що у ВНЗ МОЗ України будуть створені належні умови та вжито заходів для активізації діяль- 
ності науково-педагогічних фахівців з підготовки навчально-методичної літератури, зокрема шляхом запровадження рейтингу науково-педагогічних працівників та рейтингу кафедр.

Таблиця 17. Кількість електронних видань, які надійшли до фондів бібліотек ВНЗ протягом 2011 - 2015 рр.

(станом на 01.09.2015 р.)

\begin{tabular}{|c|c|c|c|c|c|c|c|c|c|}
\hline \multirow{3}{*}{ ВН3 } & \multirow{3}{*}{$\begin{array}{c}\text { Кількість } \\
\text { електрон- } \\
\text { них видань }\end{array}$} & \multicolumn{8}{|c|}{3 них: } \\
\hline & & \multicolumn{2}{|c|}{$\begin{array}{c}\text { з грифами МОН, МОЗ } \\
\text { України, ЦМК }\end{array}$} & \multirow{2}{*}{$\begin{array}{c}\text { кількість } \\
\text { видань, } \\
\text { авторами } \\
\text { яких є фа- } \\
\text { хівці навч. } \\
\text { закладу }\end{array}$} & \multirow{2}{*}{$\begin{array}{c}\text { кількість } \\
\text { видань, які } \\
\text { надійшли } \\
\text { з дозволу } \\
\text { авторів }\end{array}$} & \multirow{2}{*}{$\begin{array}{c}\text { кількість } \\
\text { видань, які } \\
\text { отримано } \\
\text { з вільних } \\
\text { джерел }\end{array}$} & \multirow[b]{2}{*}{ укр. } & \multirow[b]{2}{*}{ poc. } & \multirow{2}{*}{$\begin{array}{c}\text { інши- } \\
\text { ми мо- } \\
\text { вами }\end{array}$} \\
\hline & & підручники & посібники & & & & & & \\
\hline БДМУ & 9 & 2 & 5 & 4 & 4 & 5 & 8 & - & 1 \\
\hline ВНМУ & 69 & - & - & - & 6 & 63 & 22 & 47 & - \\
\hline ДМА & 87 & 74 & 13 & 66 & 66 & 21 & 86 & 1 & - \\
\hline ЗДМУ & 1732 & 49 & 339 & 1662 & 1732 & - & 1309 & 136 & 285 \\
\hline ІФНМУ & 59 & 22 & 34 & 19 & 6 & 25 & 46 & 8 & 2 \\
\hline ЛНМУ & 7 & 2 & 5 & 3 & 5 & 2 & 4 & 2 & 1 \\
\hline HMY & 79 & 39 & 23 & 1 & 78 & - & 21 & 47 & 11 \\
\hline НФУ & 296 & 21 & 92 & 294 & 294 & 2 & 149 & 81 & 66 \\
\hline OHMY & 1790 & 176 & 197 & 57 & 5 & 1730 & 387 & 832 & 571 \\
\hline ТДМУ & 512 & - & 512 & 512 & - & - & 302 & 111 & 99 \\
\hline УМСA & 828 & 4 & 46 & 718 & 754 & 74 & 327 & 277 & 224 \\
\hline XHМУ & 675 & 18 & 64 & 633 & 42 & - & 325 & 238 & 112 \\
\hline Всього: & 6143 & 407 & 1330 & 3969 & 2992 & 1922 & 2986 & 1780 & 1372 \\
\hline
\end{tabular}

Для покращення стану забезпечення здобувачів вищої освіти сучасною навчальною книгою Державні установи “Центральний методичний кабінет з вищої медичної освіти МОЗ України” та “Центральний методичний кабінет з підготовки молодших спеціалістів МОЗ України” відповідно до наказу МОЗ України від 19.01.2015 р. № 20 “Про організацію підготовки навчальної та навчально-методичної літератури” [3] протягом 2015 та I кварталу 2016 рр. організовували проведення експертизи навчальної літератури, навчально-методичних матеріалів та інших засобів навчання у вищих навчальних закладах та закладах післядипломної освіти МОЗ України для забезпечення розгляду рукописів книг Комісією для організації підготовки навчальної та навчально-методичної літератури для осіб, які навчаються у вищих медичних (фармацевтичному) навчальних закладах та закладах післядипломної освіти MO3 України, й отримання рекомендацій MO3 України щодо їх видання.

Слід зауважити, що кількість виданих підручників, які отримали відповідні грифи МОН та МОЗ
України, включено до показників Галузевого рейтингу діяльності вищих навчальних закладів та закладів післядипломної освіти, який проводиться на виконання наказу МОЗ України від 22.11.2013 р. № 1000 “Про рейтинг оцінювання діяльності вищих навчальних закладів IV рівня акредитації та закладів післядипломної освіти MO3 України”. Окрім того, наявність виданого підручника чи навчального посібника, що рекомендований $\mathrm{MOH}$ України, іншим центральним органом виконавчої влади, аналізується для визначення рівня наукової та професійної активності науково-педагогічного працівника відповідно до Ліцензійних умов, затверджених Постановою Кабінету Міністрів України від 30.12.2015 р. № 1187.

Найбільшу кількість рукописів, які отримали у 2015 р. рекомендації МОЗ України щодо їх видання, підготовлені авторськими колективами за участі фахівців: ВДНЗ України "Українська медична стоматологічна академія” (33); ВДНЗ “Буковинський державний медичний університет” (23), Запорізького державного медичного університету (16) (табл. 18). 
Таблиця 18. Кількість рукописів, які отримали у 2015 р. рекомендації МОЗ України щодо їх видання

\begin{tabular}{|l|c|c|c|c|c|c|c|c|c|c|}
\hline \multicolumn{1}{|c|}{ ВНЗ } & БДМУ & ВНМУ & ДМА & ЗДМУ & ІФНМУ & ЛНМУ & НМУ & НФаУ & ОНМУ & ТДМУ \\
\hline Кількість підручників & 2 & 1 & & 1 & & & & & 1 & 1 \\
\hline Кількість посібників & 21 & 2 & 10 & 15 & 4 & 2 & 12 & 2 & 3 & 4 \\
\hline Всього: & 23 & 3 & 10 & 16 & 4 & 2 & 12 & 2 & 4 & 5 \\
\hline
\end{tabular}

\begin{tabular}{|l|c|c|c|c|c|c|}
\hline \multicolumn{1}{|c|}{ ВНЗ } & УМСА & ХНМУ & ЗМАПО & ХМАПО & НМАПО & Інші ВН3 \\
\hline Кількість підручників & 1 & & & 1 & 1 & 4 \\
\hline Кількість посібників & 32 & & 2 & 2 & 13 & 7 \\
\hline Всього: & 33 & - & 2 & 3 & 14 & 11 \\
\hline
\end{tabular}

Висновки 1. Упродовж 2015 р. до Державної установи “Центральний методичний кабінет з вищої медичної освіти МОЗ України” на експертизу надійшло 158 рукописів, 3 них 144 книги отримали від МОЗ України дозволи на видання.

\section{Список літератури}

1. Про вищу освіту : Закон України від 01.07.2014 р. № 1556-VII.

2. Ліцензійні умови провадження освітньої діяльності закладів освіти : Постанова Кабінету Міністрів України від 30.12.2015 р. № 1187.

3. Про організацію підготовки навчальної та навчальнометодичної літератури : наказ МОЗ України від 19.01.2015 р. № 20.

4. План заходів МОЗ України для організації навчального процесу у вищих медичних та фармацевтичних навчальних закладах та закладах післядипломної освіти, підпорядкованих МОЗ України, в умовах режимів підвищеної готовності та надзвичайної ситуації : лист МО3 України від 10.03.2015 р. № 08.01-47/7130.

5. Підготовка електронних видань, дидактичних демонстраційних матеріалів, електронних навчальних посібників та підручників у вищих медичних навчальних закладах : методичні рекомендації, затверджені МО3 України 17.09.2015 р.

6. Підготовка електронних навчальних матеріалів (електронних підручників та навчальних посібників) до видання : методичні рекомендації лист МОЗ України від 27.10.2015 р. № 08.01-47/34048.

7. Порядок висунення Міністерством освіти і науки України підручників на здобуття Державної премії в галузі науки і техніки : рішення колегії Міністерства освіти і науки України від 26.06.2014 р. № 4/6-19.
2. Належне забезпечення студентів навчальною літературою, у тому числі електронними виданнями, є важливою та невід'ємною складовою забезпечення якості освітньої діяльності на виконання статті 16 розділу V Закону України “Про вищу освіту”.

8. Особливості підготовки навчальної літератури в сучасних умовах / О. П. Волосовець, Ю. С. П’ятницький, Л. В. Соколова [та ін.] // Реалізація Закону України “Про вищу освіту” у вищій медичній та фармацевтичній освіті України : матеріали Всеукр. навч.-наук. конф. $з$ міжнар. участю, присвяченої пам'яті ректора, чл.-кор. НАМН України, проф. Леоніда Якимовича Ковальчука. - Тернопіль : ТДМУ, 2015. - С. 12-18.

9. Динаміка забезпечення студентів навчальною літературою в сучасних умовах / О. П. Волосовець, Ю. С. П’ятницький, Л. В. Соколова [та ін.] // Досягнення і перспективи впровадження кредитно-модульної системи організації навчального процесу у вищих медичних (фармацевтичному) навчальних закладах України : матеріали Всеукр. навч.-наук. конф. 3 міжнар. участю. - Тернопіль : ТДМУ, 2014. - С. 435-441.

10. Національний підручник - важлива складова організації підготовки фахівців у вищих медичних та фармацевтичних навчальних закладах / М. С. Осійчук, О. П. Волосовець, І. С. Вітенко [та ін.] // Кредитномодульна система організації навчального процесу у вищих медичних (фармацевтичному) навчальних закладах України на новому етапі : матеріали Х ювілейної Всеукр. навч.-наук. конф. з міжнар. участю. - Тернопіль : ТДМУ, 2013. - C. 29-34. 